\title{
CAMPUR KODE DAN ALIH KODE DALAM PERCAKAPAN DI LINGKUP PERPUSTAKAAN UNIVERSITAS BENGKULU
}

\author{
Laiman Akhii, Ngudining Rahayu, dan Catur Wulandari \\ Program Studi Pendidikan Bahasa dan Sastra Indonesia \\ Jurusan Pendidikan Bahasa dan Seni \\ FKIP Universitas Bengkulu \\ Jackflat05@gmail.com
}

\begin{abstract}
Abstrak
Tujuan penelitian ini untuk mendeskripsikan wujud campur kode, jenis alih kode, faktor penyebab terjadinya campur kode, dan faktor penyebab terjadinya alih kode dalam percakpan di lingkup perpustakaan Universitas Bengkulu. Metode yang digunakan dalam menganalisis data adalah metode deskriptif kualitatif. Teknik pengumpulan data dalam penelitian ini dilakukan dengan teknik dokumentasi yaitu dengan merekam percakapan di lingkup perpustakaan Universitas Bengkulu dan mewawancarai narasumbernya. Langkahlangkah analisis dilakukan dengan tahapan: 1) Transkripsi data, 2) identifikasi data, 3) klasifikasi data, 4) reduksi data, 5) analisis data, 6) kesimpulan, dan 7) validasi data. Hasil analisis yang diperoleh dalam enelitian ini adalah: (1) wujud campur kode dalam percakapan di lingkup perpustakaan Universitas Bengkulu yang terjadi pada wujud kata, frasa, klaussa, dan yang berwujud baster. (2) jenis alih kode dalam percakapan di lingkup perpustakaan Universitas Bengkulu yang terjadi pada jenis alih kode intern dan jenis alih kode ekstern. Adapun (3) faktor-faktor yang menyebabkan terjadinya campur kode karena: 1) faktor kebahasaan, 2) faktor kebiasaan, 3) faktor tidak ada ungkapan yang tepat dalam bahasa yang sedang dipakai, dan 4) faktor latar belakang sikap penutur. (4) faktor-faktor yang menyebabkan terjadinya alih kode karena: 1) faktor menyesuaikan kode yang dipakai lawan bicara, 2) faktor kehadiran orang ketiga, 3) faktor penutur, 4) faktor sekedar bergengsi, 5) faktor tujuan untuk mengungkapkan sesuatu, dan 6) faktor menunjukkan bahasa pertama.
\end{abstract}

\section{Kata kunci: campur kode, alih kode, percakapan, perpustakaan Universitas Bengkulu}

\begin{abstract}
The purpose of this study is to describe the form of mixed code, the type of code transfer, the factors causing code interference, and the factors causing the transfer of code in the conversation in the library scope of University of Bengkulu. The method used in analyzing the data is descriptive qualitative method. Data collection technique in this research is done by documentation technique that is by recording conversation in library scope of University of Bengkulu and interviewing informant. The steps of analysis are done by stages: 1 ) Transcription data, 2) data identification, 3) data classification, 4) data reduction, 5) data analysis, 6) conclusion, and 7) data validation. The results of the analysis obtained in this research are: (1) the form of mixed code in the conversation in the library scope of Bengkulu University that occurs in the form of words, phrases, clauses, and tangible baster. (2) the type of code transfer in a conversation in the library scope of Bengkulu University that occurs on the type of internal code transfer and the type of external code transfer. As for (3) factors causing code interference due to: 1) language factor, 2) habit factor, 3) no exact expression factor in language being used, and 4) background factor of speaker's attitude. (4)
\end{abstract}


factors that cause the transfer of code because: 1) factor adjusting the code used by the person, 2) third person presence factor, 3) speaker factor, 4) just prestigious factors, 5) the purpose factor to express something, and 6) factor indicates the first language.

\section{Keyword: mixed code, code transfer, conversation, library University of Bengkulu}

\section{PENDAHULUAN}

Bahasa merupakan alat komunikasi dan interaksi yang dimiliki manusia untuk berhubungan dengan yang lain, sehingga terjalin suatu pergaulan dan perhubungan yang baik di antara mereka. Bahasa bagi mereka merupakan suatu media yang dapat dipakai untuk bersosialisasi. Pada umumnya bahasa yang natural atau alami adalah bahasa atau interaksi dalam bentuk lisan atau percakapan, karena di dalamnya terdapat maksud atau pesan yang ingin disampaikan secara spontan dan tanpa proses edit. Oleh karena itu, bahasa memilki peran penting dalam masyarakat.

Setiap individu disebut sebagai makhluk sosial karena saling membutuhkan satu dengan yang lainnya. Seperti yang disampaikan Nababan (1991:46), manusia bukan makhluk individu, melainkan makhluk sosial yang di dalam kesehariannya membutuhkan yang namanya bahasa. Apabila seseorang tidak dapat menggunakan bahasa untuk berinteraksi dalam kehidupan bermasyarakat, maka seseorang itu akan kehilangan kesanggupannya sebagai makhluk sosial.

$\begin{array}{clr}\text { Setiap } & \text { penutur mempunyai } \\ \text { kemampuan } & \text { komunikatif }\end{array}$
kemampuan berbahasa serta kemampuan mengungkapkan sesuai dengan fungsi dan situasi serta norma-norma pemakaian dalam konteks sosialnya. Di dalam kajian ilmu sosiolinguistik terdapat beberapa dimensi yang harus diperhatikan yaitu: identitas sosial penutur, identitas sosial pendengar, lingkungan sosial terjadinya tindak tutur, analisis sinkronik dan diakronik, penilaian sosial yang berbeda dari penutur, tingkatan variasi dan ragam linguistik.

De Saussure (dalam Chaer dan Agustina, 2010:2) menyebutkan bahwa bahasa adalah suatu lembaga kemasyarakatan, yang sama dengan lembaga kemasyarakatan lain, seperti perkawinan, pewarisan harta, dan sebagainya. Para pakar di bidang bahasa memberi perhatian lebih terhadap dimensi kemasyarakatan bahasa karena menyebabkan terjadinya ragam-ragam bahasa.

Bahasa di dalam masyarakat memiliki fungsi yang sangat luas. Menurut Chaer dan Agustina (2010:14) fungsi bahasa adalah alat untuk berinteraksi atau alat untuk berkomunikasi, dalam arti alat untuk menyampaikan pikiran, gagasan, konsep, dan juga perasaan. Sehingga peran bahasa dalam kehidupan masyarakat sangat penting dan tidak tergantikan. Maka masyarakat dituntut untuk menggunakan bahasa degan bijaksana supaya pesan yang ingin disampaikan dapat dengan mudah diterima oleh orang lain.

Menurut Mackey dan Fishman (melalui Chaer dan Agustina, 2010:84), kedwibahasaan diartikan sebagai penggunaan dua bahasa oleh seorang penutur dalam pergaulannya dengan orang lain secara bergantian. Kedwibahasaan bukanlah gejala bahasa, melainkan sifat (karakter) penggunaan bahasa. Orang yang dapat menggunakan kedua bahasa itu disebut dwibahasawan. Sebagai contoh, masyarakat Bengkulu selain menguasai bahasa Bengkulu sebagai bahasa Ibu, juga menguasai bahasa Indonesia sebagai bahasa komunikasi. 
Dalam keadaan kedwibahasaan ini maka munculah istilah Alih Kode dan Campur Kode. Menurut Suwito (1983:39) apabila terdapat dua bahasa atau lebih digunakan secara bergantian oleh penutur yang sama akan terjadilah kontak bahasa. Sehingga terjadilah adanya campur kode dan alih kode tersebut. Dalam kondisi yang demikian maka terjadilah peristiwa saling kontak antara bahasa yang satu dengan bahasa yang lainnya (language contacts) dalam peristiwa komunikasi. Campur kode dan alih kode selalu melekat pada kehidupan sehari-hari terutama dalam percakapan dengan orang lain.

Campur Kode dan alih kode seringkali terjadi si suatu tempat yang di dalamnya terdapat berbagi etnis, suku, bahasa, dan ragam budaya. Salah satu fenomena yang terjadi di Bengkulu misalnya, dalam skala wilayah banyak mahasiswa dari luar yang menuntut ilmu di universitas-universitas yang ada di Bengkulu seperti mahasiswa dari Papua, Padang, Jambi, Medan, Palembang, Bangka, dan Lampung. Dalam posisi ini mereka membawa ciri khas masing-masing daerah, baik suku, etnis, bahasa, agama, maupun sosial dan budaya. Kondisi ini mengharuskan mahasiswa beradaptasi dengan lingkungan di mana ia tinggal sementara selama menuntut ilmu. Hal ini karena mahasiswa tersebut akan bertemu dan berinteraksi dengan mahasiswa lain yang beranekaragam. Misalnya, mahasiswa luar Bengkulu harus bisa beradaptasi dengan sosial dan budaya yang ada di Bengkulu. Tidak hanya mereka yang harus bisa beradaptasi, tetapi walaupun samasama berasal dari Bengkulu harus tetap bisa beradaptasi karena masing-masing individu mempunyai ciri khas yang berbeda-beda.

Salah satu bentuk interaksi dan komunikasi mahasiswa yaitu berkomunikasi menggunakan bahasa. Dalam berkomunikasi mahasiswa tidak hanya menggunakan bahasa nasional yaitu bahasa Indonesia, tetapi juga menggunakan bahasa daerah (bahasa Ibu) masing-masing. Oleh karena bahasa sering dipakai sebagai ciri etnik, maka bahasa daerah (bahasa ibu) adalah alat identitas sosial dan budaya.

$$
\text { Hasil observasi awal di }
$$

perpustakaan Universitas Bengkulu, penulis menemukan contoh ujaran alih kode dan campur kode, seperti:

Anton : Baik kawan-kawan sebelum kita mulai rapat kita sore ini tolong yang di belakang kita buat melingkar saja, ya

Anton : Ya, baik kita mulai saja rapat kita. Seperti yang telah saya share di grup, agenda rapat kita pada hari ini yaitu mengenai Proker kita untuk satu bulan ke depan. Langsung saja siapa yang punya Proker untuk dijalankan silahkan

Valen : Bagaiman kalau...

Anton : Sebentar kawan Valen, dayah tolong kamu catat ya?

Dayah : lya, Mas

Anton : Monggo hehe (mempersilahkan kepada Valen)

Dayah : Apa-apaan koh mas Anton kie ndadak ngomong bahasa Jawa (apa-apaan kak Anton ini bicara bahasa Jawa segala)

Anton : ora papa setitek-setitek. Monggo kawan Valen (tidak apa sedikitsedikit. Silahkan kawan Valen)

Valen : Saya usul bagaimana kalau sekolah pesisir kita aktifkan kembali

Anton : Baik, sebelumnya ini langsung kita bahas atau kita catat semua dulu? Pada data di atas, tuturan terjadi di perpustakaan Universitas Bengkulu lantai 1 pada sore hari. Sekumpulan mahasiswa yang tergabung dalam organisasi Liga Mahasiswa Nasional untuk Demokrasi (LMND) sedang mengadakan rapat santai. Alih kode pada percakapan di atas 
dilakukan oleh Anton, awalnya Anton membuka rapat dengan menggunakan ragam formal bahasa Indonesia, saat Anton mempersilahkan kepada Valen untuk menyampaikan argumennya, ia beralih ke bahasa Jawa. Anton beralih dari bahasa Indonesia ke bahasa Jawa karena faktor latar belakang sikap penutur, yakni Anton merupakan keturunan Jawa

Campur kode pada percakapan di atas juga dilakukan oleh Anton, Anton membuka obrolan dengan menyisipkan kata dari bahasa Inggris ke dalam bahasa Indonesia yaitu kata share, pada kata dalam bahasa Indonesia yaitu 'bagikan' sehingga kalimat tersebut menjadi "Ya baik kita mulai saja rapat kita. Seperti yang telah saya 'bagikan' di grup, agenda rapat kita pada hari ini yaitu mengenai Proker kita untuk satu bulan ke depan. Langsung saja siapa yang punya Proker untuk dijalankan silahkan". Campur kode yang dilakukan Anton di latarbelakangi oleh faktor kebahasaan, Anton memiliki kemampuan berbahasa lain selain bahasa Ibu, selain itu kata 'share' sudah familiar di kalangan mahasiswa.

Penelitian semacam ini sudah pernah dilakukan, tetapi objeknya berbeda. Penelitian sejenis seperti ini telah dilakukan oleh Fitria Farida (2012) yang berjudul "Alih Kode dalam Acara Opera Van Java di Trans 7." Skripsi Fitria ini menetapkan objek penelitian pada acara talk show Opera Van Java yang banyak menggunakan kosakata bahasa Jawa. Penelitian alih kode juga dilakukan oleh Mundianita Rosita (2011) yang berjudul "Alih Kode dan Campur Kode Bahasa Jawa dalam Rapat Ibu-ibu PKK di Kepatihan Kulon Surakarta" Penelitian ini mendeskripsikan adanya bentuk alih kode dan campur kode berupa kata, frasa, klausa, dan kalimat pada bahasa anggota PKK, beserta faktor penyebabnya.

Pada lingkungan sosial dalam hal ini dalam lingkungan kampus, pemakaian bahasa yang digunakan oleh para mahasiswa di perpustakaan Universitas Bengkulu mempunyai keunikan dan banyak ragam bahasa yang digunakan karena para mahasiswanya terdiri dari banyak suku, ras, agama, sosial, dan budaya sehingga memungkinkan terjadi variasi kebahasaan. Pada penelitian ini, penulis akan memaparkan tentang jenis alih kode, wujud campur kode, dan faktor penyebab terjadinya alih kode dan campur kode dalam percakapan mahasiswa di perpustakaan Universitas Bengkulu. Berdasarkan latar belakang tersebut maka judul penelitian ini adalah "Campur Kode dan Alih Kode dalam Percakapan di Lingkup Perpustakaan Universitas Bengkulu".

Tujuan penelitian ini untuk memperoleh hasil wujud campur kode, jenis alih kode, faktor penyebab terjadinya campur kode, dan faktor penyebab terjadinya alih kode dalam percakapan di lingkup perpustakaan Universitas Bengkulu.

\section{METODE}

Metode penelitian yang digunakan dalam penelitian ini adalah metode penelitian deskriptif kualitatif. Penelitian deskriptif yang dimaksud adalah mengidentifikasi, menganalisis, dan mendeskripsikan data. Metode penelitian deskriptif adalah penelitian yang semata-mata hanya berdasarkan pada fakta yang ada atau fenomena yang memang secara empiris hidup pada penutur-penuturnya, sehingga data yang dihasilkan atau yang dicatat berupa paparan seperti apa adanya. Lebih lanjut penelitiian deskriptif tidak mempertimbangkan benar salahnya penggunaan bahasa oleh penuturpenuturnya, karena hal itu merupakan cirinya yang pertama dan terutama (Sudaryanto, 1988: 62)

Djajasudarma

menjelaskan bahwa (penelitian) deskriptif 
merupakan gambaran ciri-ciri data secara akurat sesuai dengan sifat alamiah itu sendiri. Penelitian deskriptif dalam penelitian ini adalah upaya untuk menggambarkan bentuk lingual alih kode dan campur kode dalam percakapan di lingkup perpustakaan Universitas Bengkulu. Data digambarkan secara objektif dan apa adanya berdasarkan apa yang penulis dapatkan.

Penggunaan metode kualitatif pada penelitian ini merupakan usaha strategi kerja dalam menganalisis objek penelitian berdasarkan rumusan masalah yang akan dipecahkan yaitu jenis alih yang digunakan, wujud campur kode, dan faktor penyebab terjadinya alih kode dan campur kode oleh percakapan di lingkup perpustakaan Universitas Bengkulu.

Data yang digunakan adalah ujaran di lingkup perpustakaan Universitas Bengkulu yang mengandung campur kode dan alih kode.

Sumber data dalam penelitian kualitatif ini adalah proses komunikasi di lingkup perpustakaan Universitas Bengkulu. Penulis menggunakan teknik rekam dan dilanjutkan dengan mewawancarai penutur untuk mengetahui faktor-faktor terjadinya campur kode dan alih kode.

Teknik pengumpulan data yang digunakan dalam enelitian ini dilakukan dengan teknik rekam sebagai data utama dan teknikwawancara sebagai data pendukung.

\section{HASIL DAN PEMBAHASAN}

Pada bagian ini penulis akan membahas mengenai permasalahanpermasalahan yang telah dirumuskan pada rumusan masalah penelitian ini, yakni mendeskripsikan tentang wujud campur kode, jenis alih kode, dan faktor yang menyebabkan terjadinya campur kode dan alih kode dalam percakapan di lingkup perpustakaan Universitas Bengkulu.
Keempat rumusan masalah tersebut akan dibahasa secara lebih rinci di bawah ini.

Dalam penelitian ini ditemukan adanya wujud campur kode dan jenis-jenis alih kode yang terjadi dalam percakapan di lingkup perpustakaan Universitas Bengkulu.

Wujud campur kode tersebut meliputi: (a) unsur yang berwujud kata, (b) unsur yang berwujud frasa, (c) unsur yang berwujud klausa, dan (d) unsur yang berwujud baster, sedangkan jenis-jenis alih kode meliputi: (a) alih kode intern dan (b) alih kode ekstern. Selain itu, ditemukan juga faktor-faktor yang menyebabkan terjadinya campur kode dan alih kode yang terjadi dalam percakapan di lingkup perpustakaan Universitas Bengkulu.

Adapun faktor-faktor yang menyebabkan terjadinya campur kode dalam percakapan di lingkup perpustakaan Universitas Bengkulu adalah: (a) faktor kebahasaan, (b) faktor kebiasaan, (c) faktor tidak ada ungkapan yang tepat dalam bahasa yang sedang dipakai, (d) faktor latar belakang sikap penutur, dan (e) faktor topik pembicaraan, sedangkan faktorfaktor yang menyebabkan terjadinya alih kode dalam percakapan di lingkup perpustakaan Universitas Bengkulu, adalah: (a) menyesuaikan kode yang dipakai lawan bicara, (b) kehadiran orang ketiga, (c) penutur, (d) sekedar bergengsi, (e) tujuan untuk mengungkapkan sesuatu, (f) lawan tutur, dan (g) menunjukkan bahasa pertama.

\section{Wujud Campur Kode dalam Percakapan di Lingkup Perpustakaan Universitas Bengkulu}

Campur kode yang ada di dalam percakapan di lingkup perpustakaan Universitas Bengkulu yang sering muncul ada beberapa unsur. Berikut ini akan dideskripsikan beberapa wujud campur kode yang muncul dalam percakapan dapat dibedakan berdasarkan unsur-unsur 
kebahasaan yang terlibat di dalamnya. Adapun unsur-unsur yang terlibat di dalamnya adalah (a) unsur yang berwujud kata yang disisipkan, (b) unsur yang berwujud frasa, (c) unsur yang berwujud klausa, (d) unsur yang berwujud baster.

Campur kode tersebut meliputi penyisipan bahasa Inggris ke dalam tuturan bahasa Bengkulu, penyisipan bahasa Inggris ke dalam tuturan bahasa Indonesia, penyisipan bahasa Arab ke dalam tuturan bahasa Bengkulu, Penyisipan bahasa Jawa ke dalam tuturan bahasa Bengkulu, penyisipan bahasa Korea ke dalam tuturan bahasa Bengkulu, penyisipan bahasa Palembang ke dalam tuturan bahasa Bengkulu, penyisipan bahasa Indonesia ke dalam tuturan bahasa Bengkulu, penyisipan bahasa Selatan ke dalam tuturan bahasa Bengkulu, dan penyisipan bahasa Rejang ke dalam tuturan bahasa Bengkulu. Berikut ini akan dijelaskan wujud-wujud campur kode tersebut.

\section{Campur Kode Berupa Kata}

Kata adalah satuan bahasa terkecil yang dapat berdiri sendiri. Berikut penulis akan menguraikan beberapa wujud campur kode yang berupa kata dalam percakapan di lingkup perpustakaan Universitas Bengkulu.

Data 17/5/2016/CK-AK/BING-BAR

Konteks: Peristiwa tutur terjadi pada siang hari di Perpustakaan Universitas Bengkulu. Taufik, Yuni, dan Niki sedang membicarakan mengenai skripsi yang mereka kerjakan.

Taufik : "Udim kaba revisi, Yun?"

Yuni : "Mpai sutik aku dapat tanda tangan, Fik. Kaba?"

Taufik : "Semegi"

Niki : "Kau kek siapo lagi, Fik?"

Taufik: "Masih banyak belum dapat ambo, Ki"

Niki : "Lemak nian kamu e, ambo sidang bae belum"
Taufik : "Bentar lagi Acc kau tu Nik, enak pembimbing kau tu"

Niki : "Aamiin, semoga ajo. Syukron, Fik"

Pada Data 17/5/2016/CK-AK/BING-BAR di atas dapat dilihat proses pembentukan campur kode yang berwujud kata dalam bahasa asing, yakni penyisipan kata bahasa Inggris dan bahasa Arab ke dalam bahasa Bengkulu. Kata Acc yang digunakan oleh Taufik dalam cuplikan di atas adalah singkatan dari Accepted yang berarti 'diterima', sedangkan kata Aamiin yang digunakan oleh Niki dalam cuplikan di atas berarti 'kabulkanlah do'a kami'. Data tersebut padanan dalam bahasa Indonesia menjadi:

Taufik : "Sudah kamu revisi, Yun?"

Yuni : "Saya baru satu mendapat tanda tangan, Fik. Kamu?"

Taufik : "Sama"

Niki : "Kamu sama siapa lagi, Fik?"

Taufik : "Masih banyak belum saya, Ki"

Niki : "Enak sekali kalian, Saya sidang saja belum"

Taufik : "Sebentar lagi diterima punya kamu itu Nik, enak pembimbing kamu tu"

Niki : "Kabulkanlah do'a kami, semoga saja. Terima kasih, Fik"

\section{Campur Kode Berupa Frasa}

Frasa adalah satuan gramatik yang terdiri dari dua kata atau lebih yang tidak melampaui batas fungsi klausa (Ramlan, 2001:138). Berikut penulis akan menguraikan beberapa bentuk campur kode berupa frasa dalam percakapan dilingkup perpustakaan Universitas Bengkulu.

Data 17/5/2016/CK-AK/BING

Konteks: Peristiwa tutur terjadi pada siang hari di Perpustakaan Universitas Bengkulu. Yuni, Niki dan Taufik sedang 
membicarakan mengenai lowongan pekerjaan untuk lulusan SMA.

Yuni : "Ado tedengar job vacancy untuk tamatan SMA, dak?"

Niki : "Belum ado, Yun"

Taufik : "Ado kemaren tu orang broadcast di BBM"

Yuni : "Di mano?"

Taufik : "Kelak ambo kirim"

Yuni : "Ah, Ambo BBM kemaren ajo idak kau read"

Taufik : "Idak jelas sih, haha"

Yuni : "Issss, ambo delcont kau kelak".

Taufik : "Ambo invite lagi yak"

Pada Data 17/5/2016/CK-AK/BING di atas dapat dilihat proses pembentukan campur kode yang berwujud frasa dalam bahasa asing, yakni penyisipan frasa bahasa Inggris ke dalam bahasa Bengkulu. Frasa job vacancy yang digunakan oleh Yuni dalam cuplikan di atas berarti 'lowongan pekerjaan'. Yuni dan Taufik juga menyisipkan frasa $B B M, B B M$ merupakan singkatan dari BlackBerry Messenger, dalam konteks ini BlackBerry Messenger merupakan aplikasi android untuk mengirim pesan ke semua kontak $B B M$. Data tersebut padanan dalam bahasa Indonesia menjadi:

Yuni : "Ada terdengar lowongan pekerjaan untuk tamatan SMA, tidak?"

Niki : "Belum ada, Yun"

Taufik : "Ada kemarin orang siarkan di BBM"

Yuni : "Di mana?"

Taufik : "Nanti saya kirim"

Yuni : "Saya BBM kemarin aja nggak kamu baca"

Taufik : "Tidak jelas sih, haha"

Yuni : "Saya hapus kontak kamu nanti"

Taufik : "ya saya undang lagi".

Campur Kode Berupa Klausa
Klausa merupakan satuan gramatik yang terdiri dari S P bak disertai O, PEL, dan KET ataupun tidak. Dengan ringkas, klausa adalah S P (O) (PEL) (KET). Tanda kurung menandakan bahwa apa yang terletak dalam kurung itu bersifat mana suka, artinya boleh ada, boleh juga tidak ada (Ramlan, 2001:79). Berikut penulis akan menguraikan wujud campur kode berupa klausa dalam percakan di lingkup perpustakaan Universitas Bengkulu.

Data 6/10/2016/CK/BING

Konteks: Percakapan terjadi pada sore hari di perpustakaan Universitas Bengkulu. Razy, Dian, dan Titin sedang membicarakan mengenai permainan Pokemon Go sambil menunggu teman-teman yang lain untuk mengerjakan tugas.

Dian : "Pokemon Go tu padeknyo difilm kan"

Razy : "Lah ngapo"?

Dian : "Laris. Padek nian Amerika tu"

Titin : "Perasaan ambo idak terlalu penting lah Pokemon Go tu"

Razy : "Perasaan segalo game idak ado yang penting lah"

Titin : "Ado game yang lagi hits kini tu, yang nanam-nanam tu nah, yang perkebunan".

Razy : "Game anak-anak tu?"

Titin : "I want to be a farmer keceknyo tu, kalo yang nanam-nanam tu".

Pada Data 6/10/2016/CK/BING di atas dapat dilihat proses pembentukan campur kode yang berwujud klausa yakni penyisipan klausa bahasa Inggris ke dalam tuturan bahasa Bengkulu. Klausa $i$ want to be a farmer yang digunakan oleh Titin dalam cuplikan di atas berarti 'saya ingin menjadi seorang petani'. Data tersebut padanan dalam bahasa Indonesia menjadi

Dian : "Pokemon Go tu bagusnya difilm kan" 
Razy : "kenapa"?

Dian : "Laris. Pintar sekali Amerika tu"

Titin : "saya rasa tidak terlalu penting Pokemon Go tu"

Razy : "Perasaan semua permainan tidak ada yang penting"

Titin : "Ada permainan yang lagi tenar sekarang, yang nanam-nanami tu yang perkebunan".

Razy : "permainan anak-anak tu?"

Titin : "saya ingin menjadi seorang petani katanya di situ, kalau yang nanam-nanam itu".

\section{Campur Kode Berupa Baster}

Baster merupakan hasil perpaduan dua unsur bahasa yang berbeda, membentuk satu makna (Suwito, 1983:76). Baster merupakan bentuk yang tidak asli, artinya bentuk ini terjadi karena perpaduan antara afiksasi bahasa satu dengan unsur bahasa lain.

Data 17/5/2016/CK-AK/BING

Konteks: peristiwa tutur terjadi pada siang hari di perpustakaan Universitas Bengkulu. Tria bertemu dengan Vera yang sedang membaca buku dan membicarakan mengenai sidang skripsi.

Tria : "Hoi, ngapei ko disini?"

Vera : "Biase Wifi-an, nyaka'r bahan skripsi, coy. Ko lah 'adu sidang lum?"

Tria : "Aku tige ha'ri, coy, datang awu".

Vera : "Aii lemak e, aku negal agi juge nunggu $A C C$ dosen. Ko ndak

kemane weekend ni?"

Tria : "Ko kurang picnic? Pening palak mu?"

Vera : "Ae pening, ndak de?".

Tria : "Jadi, kelak ku WA kangau. Aku duluan awu, tadi aku janjian dengan dosen".

Pada Data 17/5/2016/CK-AK/BING di atas dapat dilihat proses pembentukan campur kode yang berwujud baster yakni penyisipan dari bahasa Inggris wifi-an. Kata wifi merupakan singkatan dari Wireless Fidelity yaitu sebuah media penghantar komunikasi data tanpa kabel yang bisa digunakan untuk komunikasi atau mentransfer program dan data dengan kemampuan yang sangat cepat, sedangkan -an merupakan imbuhan dari bahasa Indonesia yang berarti 'memakai'. Contoh tersebut padanan dalam bahasa Indonesia menjadi

Tria : "ngapain kamu disini?"

Vera : "Biasa Wifi-an, nyari bahan skripsi. Kamu sudah sidang belum?"

Tria : "Aku tiga hari lagi, datang ya".

Vera : "enaknya, aku sebentar lagi nunggu diterima dosen. Kamu mau kemana liburan ni?"

Tria : "kamu kurang piknik? Kepala mu pusing?"

Vera : "iya pusing, mau nggak?".

Tria : "Jadi, nanti ku WA. Aku duluan ya, tadi aku janjian dengan dosen".

\section{Jenis Alih Kode dalam Percakapan di Lingkup Perpustakaan Universitas Bengkulu}

Dalam penelitian ini ditemukan adanya jenis-jenis alih kode yang terjadi dalam percakapan di lingkup perpustakaan Universitas Bengkulu. Jenis-jenis alih kode tersebut meliputi: alih kode intern dan alih kode ekstern.

Pada kajian teori, Hymes (dalam Rahardi, 2010: 20) menyebutkan apa yang disebut sebagai alih kode intern (internal code switching), yakni alih kode yang terjadi antarbahasa daerah dalam satu bahasa nasional, antardialek dalam satu bahasa daerah, atau antara beberapa ragam dan gaya yang terdapat dalam suatu dialek. Adapun yang dimaksud dengan alih kode ekstern (external code switching) yaitu apabila yang terjadi adalah antarbahasa asli dengan bahasa asing. 
Alih Kode Intern dalam percakapan di lingkup perpustakaan Universitas Bengkulu.

Alih kode intern adalah alih kode yang berlangsung antarbahasa sendiri, seperti dari bahasa Indonesia ke bahasa Jawa atau dari bahasa Indonesia ke bahasa daerah lain.

Alih kode dari bahasa Selatan ke bahasa Bengkulu

Data 17/5/2016/CK-AK/BBS-BKL

Konteks: Peristiwa tutur terjadi pada siang hari di perpustakaan Universitas Bengkulu. Taufik, Yuni, dan Niki sedang berbicara mengenai skripsi yang mereka kerjakan.

Taufik : "Udim kaba revisi, Yun?”

Yuni : "Mpai sutik aku dapat tanda tangan, Fik. Kaba?"

Taufik : "Semegi"

Niki : "Kau kek siapo lagi, Fik?"

Taufik: "Masih banyak belum dapat ambo, Ki"

Niki : "Lemak nian kamu e, ambo sidang bae belum"

Taufik : "Bentar lagi Acc (accepted) kau tu Nik, enak pembimbing kau

tu"

Niki : “amiin, semoga ajo. Syukron, Fik”

Pada Data 17/5/2016/CK-AK/BKL di atas, awalnya Taufik menggunakan bahasa Besemah Selatan saat berbicara kepada Yuni mengenai revisi skripsi, lalu Taufik beralih ke bahasa Bengkulu. Alih kode yang digunakan Taufik ditandai dengan adanya tuturan "Bentar lagi Acc kau tu Nik, enak pembimbing kau tu". Padan kata dalam bahasa Indonesia, contoh di atas menjadi

Taufik : "Kamu sudah revisi, Yun?"

Yuni : "baru satu aku dapat tanda tangan, Fik. Kamu?"
Taufik : "Sama saja"

Niki : "Kamu sama siapa lagi, Fik?"

Taufik : "Masih banyak belum saya, Ki"

Niki : "enak sekali kalian, saya sidang saja belum"

Taufik : "Sebentar lagi di terima kamu itu Nik, enak pembimbing kamu tu"

Niki : "amiin, semoga saja. Terima kasih, Fik"

\section{Alih Kode Ekstern dalam percakapan di Lingkup Perpustakaan Universitas Bengkulu}

Alih kode eksern yaitu alih kode yang terjadi antara bahasa Indonesia atau daerah lain di Indonesia ke bahasa Asing. Alih kode bersifat ekstern apabila alih kode itu terjadi antara bahasa asli dengan bahasa Asing.

1) Alih kode dari bahasa Bengkulu ke dalam bahasa Arab

\section{Data 21/6/2016/CK-AK/BKL-BAR \\ Konteks: Peristiwa tutur terjadi pada siang hari di perpustakaan Universitas Bengkulu. Pram dan Ana yang sedang membaca buku dan dihampiri oleh Yuyun.}

Pram : "Ngapoin lagi yang lah S.Pd. ko masih ke perpus?"

Yuyun : "Tambah pening ado ambo udem sidang ni. Revisi banyak tegalau"

Pram : "Yang jelas lah aman kau tu bro. Nah kami apalah daya"

Yuyun : "Guyur bro, sidang kamu tu bentar lagi"

Pram : "Aaminn ya Allah"

Yuyun : "Amin"

Pram : "Syukron"

Yuyun : "Jaza-killah khairan katsiira"

Pada Data 21/6/2016/CK-AK/BKL-BAR di atas, awalnya Pram menggunakan bahasa Bengkulu saat berbicara kepada Yuyun. Lalu kemudian dengan sadar beralih kode ke bahasa Arab dengan maksud meminta 
dikabulkan doa kepada Tuhan yang ditandai kata "Aaminn ya Allah". Padanan kata dalam bahasa Indonesia, contoh di atas menjadi

Pram : "Ngapain lagi yang sudah S.Pd. ni masih ke perpus?"

Yuyun : "yang ada tambah pusing saya sudah sidang ni. Revisi banyak sekali"

Pram : "Yang jelas lah aman kamu bro. Nah kami apalah daya"

Yuyun : "Guyur bro, sidang kamu tu bentar lagi"

Pram : "Kabulkanlah doa kami ya Allah"

Yuyun : "Kabulkan doa kami"

Pram : "Terima kasih"

Yuyun : "Semoga Allah melimpahkan kebaikan kepadamu"

\section{PENUTUP}

\section{Simpulan}

Berdasarkan hasil penelitian dan pembahasan yang telah dilakukan, wujud campur kode dalam percakapan di lingkup perpustakaan Universitas Bengkulu meliputi (a) unsur yang berwujud kata, (b) unsur yang berwujud frasa, (c) unsur yang berwujud klausa, dan (d) unsur yang berwujud baster. Campur kode tersebut meliputi penyisipan bahasa Inggris ke dalam tuturan bahasa Bengkulu, penyisipan bahasa Inggris ke dalam tuturan bahasa Indonesia, penyisipan bahasa Arab ke dalam tuturan bahasa Bengkulu, Penyisipan bahasa Jawa ke dalam tuturan bahasa Bengkulu, penyisipan bahasa Korea ke dalam tuturan bahasa Bengkulu, penyisipan bahasa Palembang ke dalam tuturan bahasa Bengkulu, penyisipan bahasa Indonesia ke dalam tuturan bahasa Bengkulu, penyisipan bahasa Selatan ke dalam tuturan bahasa Bengkulu, dan penyisipan bahasa Rejang ke dalam tuturan bahasa Bengkulu.

Jenis alih kode yang terjadi dalam percakapan di lingkup perpustakan Universitas Bengkulu meliputi alih kode intern dan alih kode ekstern. Alih kode tersebut meliputi: (a) alih kode dari bahasa Selatan ke bahasa Bengkulu, (b) alih kode dari bahasa Indonesia ke bahasa Bengkulu, (c) alih kode dari bahasa Bengkulu ke bahasa Kaur, (d) alih kode dari bahasa Muko-muko ke bahasa Bengkulu, (e) alih kode dari bahasa Indonesia ke bahasa Jawa, (f) alih kode dari bahasa Indonesia ke bahasa Batak, (g) alih kode dari bahasa Bengkulu ke bahasa Arab, (h) alih kode dari bahasa Bengkulu ke bahasa Inggris, dan (i) alih kode dari bahasa Kaur ke bahasa Inggris.

Faktor-faktor penyebab terjadinya campur kode di lingkup perpustakaan Universitas Bengkulu meliputi (a) faktor kebahasaan, (b) faktor kebiasaan, (c) faktor tidak ada ungkapan yang tepat dalam bahasa yang sedang dipakai, (d) faktor latar belakang sikap penutur, dan (e) faktor topik pembicaraan. Faktor yang paling sering terjadi adalah faktor kebahasaan.

Faktor-faktor penyebab terjadinya alih kode intern meliputi: (a) menyesuaikan kode yang dipakai lawan bicara, (b) kehadiran orang ketiga, (c) penutur, (d) sekedar bergengsi, (e) tujuan untuk mengungkapkan sesuatu, (f) lawan tutur, dan (g) menunjukkan bahasa pertama.

\section{Saran}

Adapun saran yang dapat disampaikan berkaitan dengan alih kode dan campur kode dalam percakapan di lingkup perpustakaan Universitas Bengkulu adalah:

1. Penggunaan alih kode dan campur kode boleh digunakan dengan cataan untuk mempermudah komunikasi di antara penutur dan lawan tutur.

2. Penggunaan alih kode dan campur kode harus disesuaikan dengan situasi dan kondisi atau konteks tuturan.

\section{DAFTAR PUSTAKA}


Badan bahasa. Alih Kode dan Campur Kode.http://badanbahasa.kemdikb ud.go.id.(diakses 12 februari 2016)

Chaer, Abdul dan Agustina, Leonie. 2010. Sosiolinguistik: Perkenalan Awal (Edisi Revisi). Jakarta: Rineka Cipta.

Farida, Fitria. 2012. Alih Kode dalam Acara Opera Van Java di Trans 7. Skripsi. Universitas Negeri Purwokerto.

Moleong, Loxy L. 2012. Metode Penelitian Kualitatif. Bandung: PT. Remaja Rosdakarya.

Nababan, PWJ. 1991. Sosiolinguistik Suatu Pengantar. Jakarta: Gramedia Pustaka Utama.

Rahardi, R. Kunjana. 2010. Kajian Sosiolinguistik Ihwal Kode dan Alih Kode. Bogor: Ghalia Indonesia.

Rosita, Mundianita. 2011. Alih Kode dan Campur Kode Bahasa Jawa dalam Rapat Ibu-ibu PKK di Kepatihan Kulon Surakarta. Skripsi. Universitas Muhamadiah Surakarta.

Sudaryanto. 1988. Metode Linguistik. Yogyakarta: Gadjah Mada University Press.

Suwito. 1983. Sosiolinguistik Teori Dan Problema. Surakarta: Fakultas Sastra Universitas Mataram. 